\title{
OPTIMIZE WIDTH OF NAVIGATIONAL CHANNELS AND SHIPS TURNING BASINS IN PORTS
}

\author{
Vytautas Paulauskas, Donatas Paulauskas, Birutė Plačienè, Valdas Lukauskas \\ Dept of Shipping, Klaipeda University, Lithuania
}

Submitted 9 March 2014; resubmitted 8 May 2014, 21 September 2014; accepted 11 December 2014;

first published online 13 July 2015

\begin{abstract}
A number of ports are located close to cities or have other limitations on approaching areas of water. The optimization of the port and the use of possible areas of water are linked with the maximum number of the ships that could enter the port. The main factor considered in the presented study is the potential possibilities of water areas used for the ships entering the port as well as manoeuvring, turning, mooring and unmooring operations performed by the largest ships.
\end{abstract}

Keywords: port area; ship; navigation safety; ship turning basins; navigational channels.

\section{Introduction}

A number of ports have limitations on improvement in areas of water. At the same time, they make attempts to increase the size and frequency of the ships entering the port or to expand the areas in some of the ports. Navigation safety in the limited areas of port waters or in some parts of the ports is the main factor to be considered as regards port development and optimization with minimum investments in port infrastructure.

Navigation channels, ship turning basins and access to quay walls are very important for the largest possible ships in order to optimize width of the navigational channels and ships turning basins in ports (PIANC 2010, 1997; Recommendations of the Committee... 2010). The optimal possible width of the navigational channel, an optimal diameter of ship turning basins and safe access to quay walls should be calculated and tested employing simulators and checked involving real ships thus starting preparation for optimizing areas of water in ports (Paulauskas 2011). Calculations and comparisons of the parameters of navigational channels and ship turning basins as well as ship manoeuvrability characteristics, particularly ship stopping distance, with the parameters of port waters are very important for the optimization of the aquatories of ports or certain parts of ports to assess the frequency of passing ships in order the largest ships could enter the specified places of ports.

With reference to exact calculations and experimental results obtained employing simulators and real ships, the maximum possible number of the vessels, depending on their parameters, that can enter ports or certain port areas and minimum investments into the development of port infrastructure is the main goal of the article.

\section{Situation in Areas of Water in Ports}

Limitations on the area of water in ports (port basins) request to be improved or maximum used for the purposes of terminal development and an increase in the capacity of the existing terminals. For example, some parts of the ports like Ventspils in the Venta River area, Gdańsk in the Martwa Wisła area, the Port of Klaipeda in Malkų Bay and some other similar ports or port areas can be considered. The above mentioned parts of the ports or port areas have very narrow navigational channels and severely limited ship turning basins. For instance, the width of the navigational channel in the port area of Martwa Wisła River in Gdańsk makes about $88 \mathrm{~m}$, and the ship turning basin is only about $300 \mathrm{~m}$ in diameter (Fig. 1). The width of the channel in the port area of the Venta River in Ventspils is about $80 \mathrm{~m}$, and the ship turning basin is about $280 \mathrm{~m}$ in diameter (Fig. 2). The width of the navigational channel at Klaipeda port in Malkų Bay is about $80 \mathrm{~m}$, and the ship turning basin is about $280 \mathrm{~m}$ in diameter (Fig. 3). At the same time, the Port of Gdańsk accepts PANAMAX container ships having a length of up to $295 \mathrm{~m}$, width - up to $32.8 \mathrm{~m}$, whereas the Port of Klaipeda in Malkų Bay -

Corresponding author: Vytautas Paulauskas

E-mail: donatasp@takas.lt 


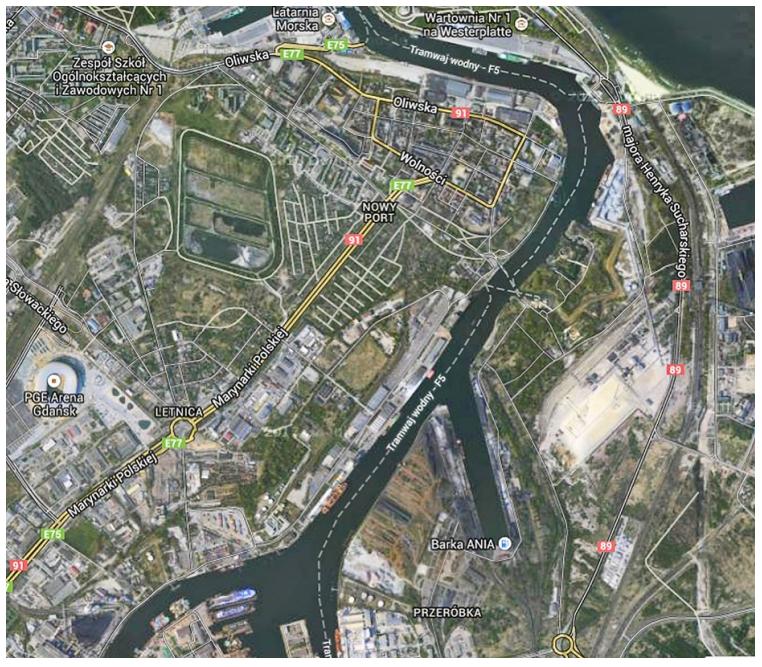

Fig. 1. A part of the Port of Gdańsk in the Martwa Wisła area (width of the navigational channel - about $88 \mathrm{~m}$, ship turning basin - about $300 \mathrm{~m}$ in diameter)

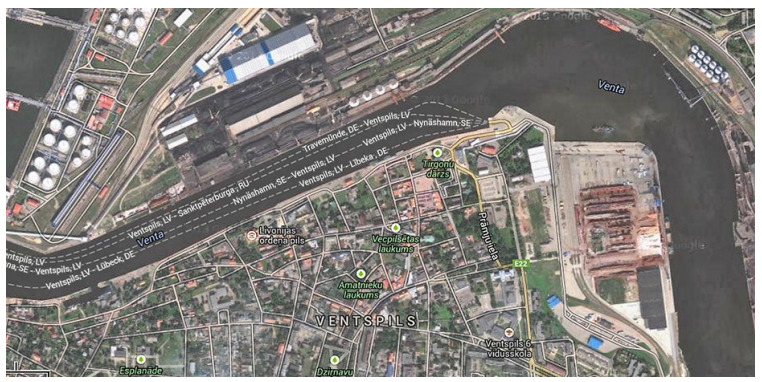

Fig. 2. A part of the Port of Ventspils in the Venta River area (width of the navigational channel $-80 \mathrm{~m}$, ship turning basin - about $280 \mathrm{~m}$ in diameter)

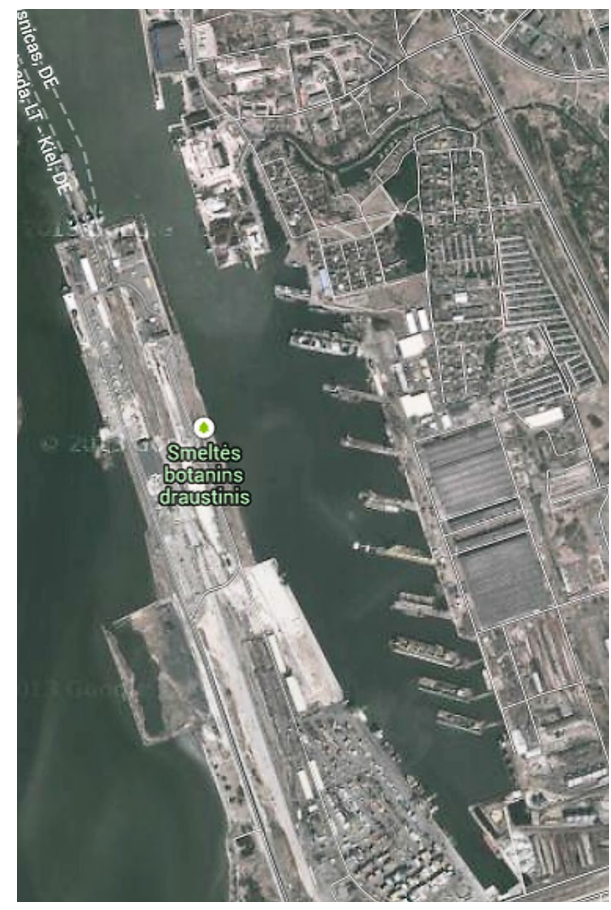

Fig. 3. A part of the Port of Klaipeda in Malkų Bay (width of the entrance channel - about $80 \mathrm{~m}$, ship turning basin $280 \mathrm{~m}$; improvement should increase the basin up to $320 \mathrm{~m}$ )
Post-PANAMAX ships having a length of up to $230 \mathrm{~m}$, width - up to $40 \mathrm{~m}$ (future prospects point to accepting the ships having the length of up to $295 \mathrm{~m}$ and the width of up to $46 \mathrm{~m}$ ). The Port of Ventspils allows entering the ships the length of which makes up to $256 \mathrm{~m}$ and width - up to $42 \mathrm{~m}$.

To increase ship length in areas of water in ports and channels is possible on the basis of accurate theoretical study, calculations and testing provided with the help of simulators, the check of real ships and the use of modern navigational systems and devices (PIANC 1995; Gucma, Montewka 2005; Paulauskas, V., Paulauskas, D. 2009; Tomczak 2008). In such cases, ship and tug masters as well as port pilots must have relevant practical experience (Paulauskas 2011).

\section{Theoretical Basis for Evaluating and Optimizing Areas of Water in Ports}

Port waters that include navigational channels, ship turning basins and access to quay walls or jetties must comply with safety requirements for ship entries, mooring, unmooring and leaving areas of water in ports. The parameters of navigational channels, including the width, depth and bend radius of the channel, depend on calculations referring to the largest ship (Paulauskas, V., Paulauskas, D. 2009):

$$
B_{c}=L \cdot \sin \beta+B \cdot \cos \beta+L \cdot \sin \Delta K+v_{c} \cdot \cos q_{c}+b_{n},
$$

where: $L$ - ship's length between perpendiculars $[\mathrm{m}]$; $B$ - ship's width $[\mathrm{m}] ; \beta$ - the angle of ship drift at the entrance to the ship turning basin or in the channel [degrees]; $\Delta K$ - ship movement around the ship's course [degrees]; $v_{c}$ - current velocity $[\mathrm{m} / \mathrm{s}] ; q_{c}$ - the angle of the current course [degrees]; $b_{n}-$ navigational margin $[\mathrm{m}]$.

The drift angle of the ship while proceeding to the channel can be assessed employing the formula (Paulauskas 1999):

$$
\beta=\operatorname{arctg} \beta=\frac{v_{d}+v_{c} \cdot \sin q_{c}}{v},
$$

where: $v$ - ship's speed in the channel (many ports accept 6 or more knots) $[\mathrm{m} / \mathrm{s}] ; v_{d}-$ the drift speed of the ship $[\mathrm{m} / \mathrm{s}] ; v_{c}-$ current velocity $[\mathrm{m} / \mathrm{s}] ; q_{c}-$ the angle of the current course [degrees].

The evaluation of wind effect determined by drift velocity can be calculated using the formula (Strem 2004):

$$
v_{d}=v_{a} \cdot \sqrt{\frac{C_{a} \cdot \rho_{1} \cdot S_{x} \cdot \sin q_{a}}{C_{y} \cdot \rho \cdot F_{d}}},
$$

where: $v_{a}$ - wind speed $[\mathrm{m} / \mathrm{s}] ; C_{a}$ - aerodynamic coefficient (1.07 can be adopted); $\rho_{1}-$ air density (calculations use $1.25 \mathrm{~kg} / \mathrm{m}^{3}$ ); $S_{x}$ - the space of projection onto a Diametrical Plane (DP) of the wind surface area of the vessel $\left[\mathrm{m}^{2}\right] ; C_{y}$ - hydrodynamic coefficient (calculations accept $1.5 \div 1.8) ; \rho$ - water density $\left[\mathrm{kg} / \mathrm{m}^{3}\right] ; F_{d}$ - the space of projection onto a DP of the underwater area of the vessel $\left[\mathrm{m}^{2}\right] ; q_{a}$ - the course angle of the wind [degrees]. 
The space of projection onto a DP of the underwater area of the vessel can be calculated using the formula (Paulauskas 2011):

$$
F_{d}=\gamma \cdot L \cdot T,
$$

where: $\gamma$ - the coefficient of the space of projection onto a DP of the underwater area of the vessel (for large ships, 0.95 can be adopted); $T$ - ship's average draft [m].

Theoretically, the width of ship turning basins and other channels followed by the ship can be calculated as follows (Paulauskas, V., Paulauskas, D. 2009):

$$
\begin{aligned}
& B_{k}=L+\Delta l+L \cdot \sin \beta+B \cdot \cos \beta+ \\
& L \cdot \sin \Delta K+P^{\prime} \cdot \sigma_{y}+b_{n},
\end{aligned}
$$

where: $\Delta l$ - additional length requested for tugs or ship movement during ship turn in the turning basin (can be accepted as the length of a towing line) [m]; $P^{\prime}-$ probability coefficient (in case of probability not less than 95\% ( $P^{\prime}$ can be accepted as 2.5); $\sigma_{y}$ - observation accuracy of ship position $[\mathrm{m}] ; b_{n}$ - navigational supplement evaluating the accuracy of ship turning basins or channel slops [m].

The drift angle of the ship in case of the absent current could be calculated as follows (Zalewski, Montewka 2007):

$$
\beta=\operatorname{arctg} \beta=\frac{v_{d}}{v},
$$

where: $v$ - ships speed at the entrance to the ship turning basin or in the channel $[\mathrm{m} / \mathrm{s}] ; v_{d}$ - the drift speed of the ship $[\mathrm{m} / \mathrm{s}]$.

When calculating the depth of ship turning basins, channels and other port waters, the points, such as maximum possible ship's draft, sounded depth, survey tolerance, siltation, squat allowance of the ship, the influence of ship rolling (heel), the response of waves in the places of action, an additional navigational margin of depth evaluating possible changes in depth and other atypical situations should be taken into account.

Ship turning basins must guaranty safe ship turn employing tugs or thrusters. The ships like containers or Ro-Ro vessels and some tankers have thrusters and can turn without tugs. If using them, a minimal width (diameter) of the turning basin can be determined with reference to the formula (Paulauskas 2011):

$$
B_{a}=L_{\max }+L_{V}+\Delta l
$$

where: $L_{\max }$ - the overall ship's length $[\mathrm{m}] ; L_{V}$ - tug's length $[\mathrm{m}]$.

For ships having thrusters, a minimal width of the turning basin should be not less than (Strem 2004; Paulauskas 2011):

$$
B_{a} \geq(1.1 \div 1.25) \cdot L_{\max } \text {. }
$$

The geometrical parameters of the turning basin must provide for navigation safety; a minimum diameter of the turning basin for tug-assisted vessel turning/ rotation under good weather conditions, i.e. wind speed below $12 \mathrm{~m} / \mathrm{s}$, should make at least:

$$
\begin{aligned}
& D_{B}=L_{\max }+0.1 \cdot L_{\max }+2 \cdot B_{V}= \\
& 1.1 \cdot L_{\max }+2 \cdot B_{V},
\end{aligned}
$$

where: $B_{V}$ - the maximum width of the tug (for example, $8 \div 10 \mathrm{~m}$ can be accepted) $[\mathrm{m}]$.

The minimum bend radius of the navigational channel could be calculated as follows:

$$
R_{B} \geq 2 \cdot L \text {. }
$$

The maximum frequency of ships, in case of the exiting one sailing line in the specified port area, is equal to:

$$
F_{T}=\frac{n}{T}
$$

where: $n$ - the number of ships that can sail in the specified place per period $T$.

Sailing time for ships in the navigational channel while performing manoeuvres in the turning basin and moving from the navigational channel or turning basin (period) could be calculated as:

$$
T=\frac{S_{N 1}}{v_{1}}+T_{T}+\frac{S_{N 2}}{v_{2}},
$$

where: $S_{N 1}$ - the length of the navigational channel from the port (channel) entrance up to the ship turning basin $[\mathrm{m}] ; v_{1}$ - ship's average speed in the navigational channel under imposed port regulations $[\mathrm{m} / \mathrm{s}] ; T_{T}$ - turning time for ships, (for large ones, it can reach $0.3 \mathrm{deg} / \mathrm{s}$, whereas for small - up to $0.5 \div 0.7 \mathrm{deg} / \mathrm{s}$ (Baublys 2003)) [s].

Period $T_{T}$ should include stopping time for the ship before turn, i.e. finally, full time close to the ship turning basin will be:

$$
T_{S}=T_{T}+t_{\text {stop }},
$$

where: $T_{T}$ - turning time for ships $[\mathrm{s}] ; t_{\text {stop }}-$ stopping time for the ship, taken depending on the stopping method of the ship [s]; in many cases, it cannot be calculated on the basis of the main formula (Paulauskas 1999; Paulauskas, V., Paulauskas, D. 2009):

$$
m \frac{d v}{d t}=R_{x}+F_{x}+F_{V}
$$

where: $m$ - ship's mass in combination with added water mass $[\mathrm{kg}] ; R_{x}$ - resistance of the ship's hull that can be calculated referring to the methods presented in (Paulauskas 2011) [N]; $F_{x}$ - the force of the ship's propeller that can be calculated employing the methods presented in (Paulauskas 2011) [N]; $F_{V}$ - tugboat bollard pull that can be calculated applying the methods presented in (Paulauskas 2011) [N].

The distance of ship stopping $S_{a}$ and time $t_{\text {stop }}$ can be found from formula (14) as:

$$
\begin{aligned}
& S_{a}=\frac{m}{2 \cdot k_{i n}} \cdot \ln \frac{k_{i n} \cdot v_{0}+\left(F_{x}+F_{V}\right)}{k_{i n} \cdot v+\left(F_{x}+F_{V}\right)} \\
& t_{\text {stop }}=\frac{m}{\sqrt{k_{\text {in }} \cdot\left(F_{x}+F_{V}\right)}} \cdot\left(\operatorname{arctg} \sqrt{\frac{k_{i n}}{F_{x}+F_{V}}} \cdot v_{0}-\right. \\
& \left.\operatorname{arctg} \sqrt{\frac{k_{i n}}{F_{x}+F_{V}}} \cdot v\right),
\end{aligned}
$$

where: $k_{i n}$ - ship inertia coefficient found using the methods presented in Paulauskas (1999). 
For practical calculations, in case of a low ship's speed usually maintained in port channels and port areas, stopping time for the ship can be accepted as:

$$
t_{\text {stop }} \leq \frac{3 \cdot L}{v_{1}} \text {. }
$$

Ship movement from the turning basin up to the quay wall or outside the navigational channel could be calculated as follows:

$$
t_{\text {g.a. }}=\frac{S_{N 2}}{v_{2}}
$$

where: $S_{N 2}$ - distance from the ship turning basin to the channel border can be accepted as the width of the navigational channel $[\mathrm{m}] ; v_{2}$ - ship movement from the ship turning basin can be accepted as the ship's towage speed, and, in general, can make up to 2 knots $(1 \mathrm{~m} / \mathrm{s})$.

The maximum number of ships per day, in case of the sailing direction of the ship in the navigational channel, can be calculated as follows:

$$
N_{S}=\frac{86400}{\frac{S_{N 1}}{v_{1}}+T_{T}+t_{\text {stop }}+\frac{S_{N 2}}{v_{2}}}-\Delta t,
$$

where: $\Delta t$ - additional time for ship movement outside the channel or ship turning basin with a possibility of other ships crossing the ship manoeuvring areas.

On the basis of the methodology presented in this article, it is possible to evaluate the maximum possibility of ports or port areas so that to attract the largest ships and the possible maximum number of vessels.

\section{Practical Case Study on the Evaluation of Width of the Navigational Channels and Ships Turning Basins in Port}

For practical evaluation, the area of the Port of Klaipeda in Malku Bay (Figs 4-12), that consists of the entrance to the navigational channel, ship turning basin and access to quay walls, or jetties, has been considered. The length of the navigational channel is about $1000 \mathrm{~m}$, the ship turning basin is located at a distance of about $500 \mathrm{~m}$ to the quay walls and the permitted speed in the navigation channel and other port areas is not more than 6 knots. The case study has been done with reference to theoretical calculations employing the methodology presented in this article, SimFlex Navigator simulator (SimFlex Navigator 2012; Thiers, Janssens 1998) and monitoring real sailing ships applying the Automatic Identification System (AIS).

The ship's speed before the entrance channel and after passing it, under the wind, cannot decrease, and therefore the results are shown in Figs 4 and 5.

The average size of the ships sailing to Malku Bay covers the length of about $150 \mathrm{~m}$ and the width of about $26 \mathrm{~m}$. Stopping distance is about $450 \div 500 \mathrm{~m}$, the average stopping time is about $250 \div 400 \mathrm{~s}$, the distance from the ship turning basin to quay walls $-500 \mathrm{~m}$ and the average speed after ship turn on the way to the quay wall is about 2.5 knots.

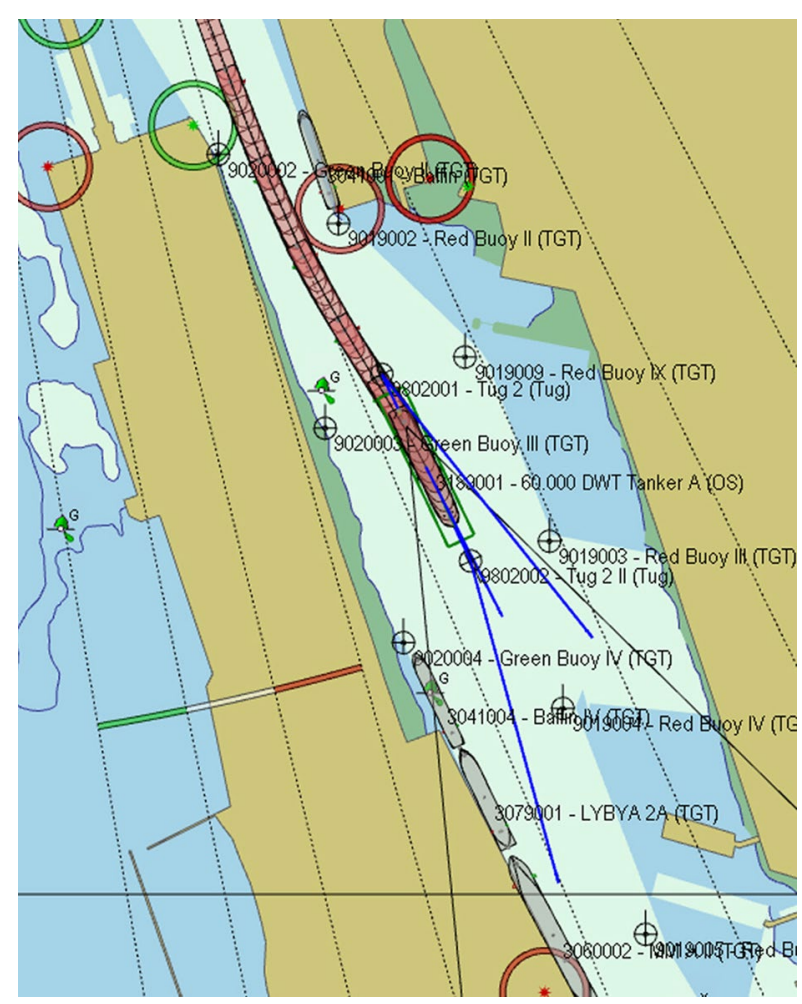

Fig. 4. Ship entry to the turning basin in Malkų Bay (electronic map)

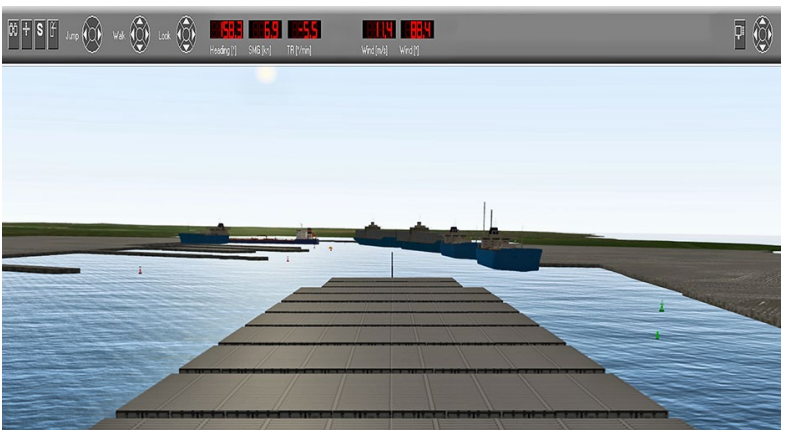

Fig. 5. The entry of a container vessel $(L=295 \mathrm{~m})$ to the turning basin in Malkų Bay (visual view)

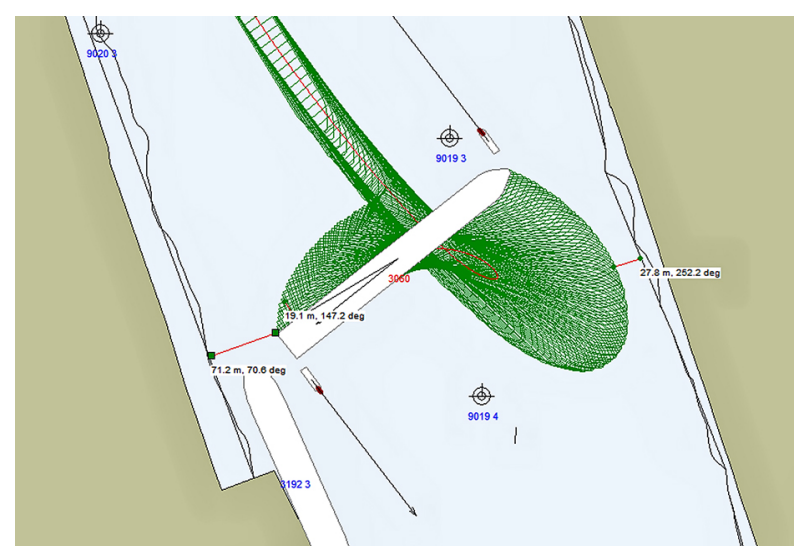

Fig. 6. A turn of a container vessel $(L=295 \mathrm{~m})$ into the ship turning basin in Malkų Bay employing $2 \times 50 \mathrm{~T}$ bollard pull tugboats (electronic map) 


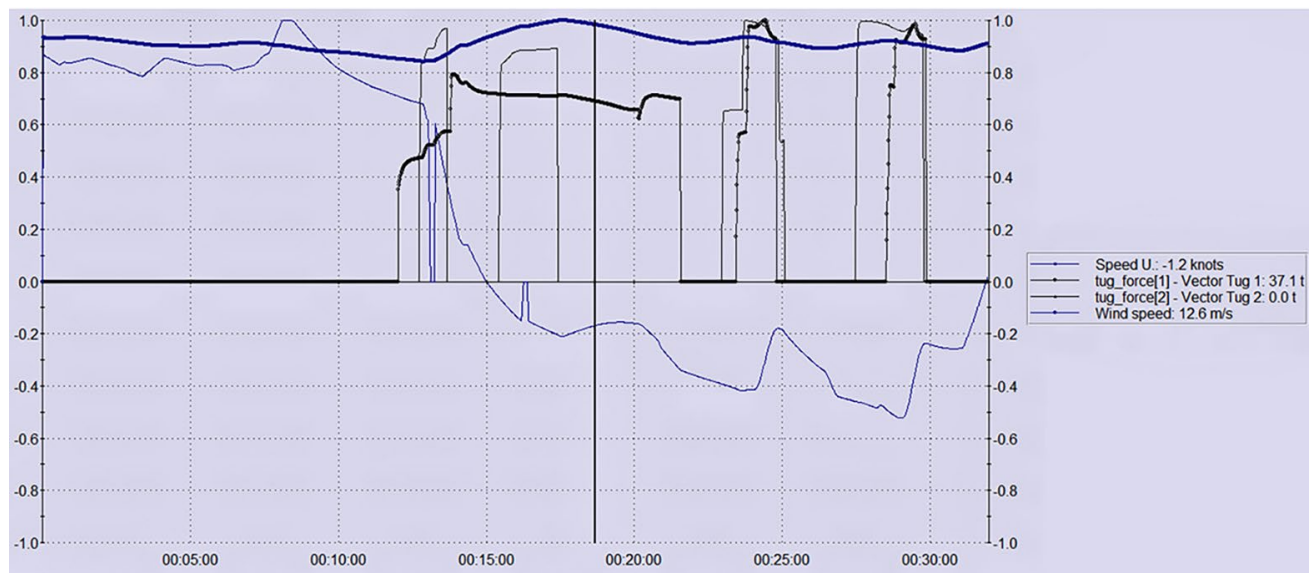

Fig. 7. The entry of a container vessel $(L=295 \mathrm{~m})$ into Malkų Bay considering the parameters of time, speed, the bollard pull of the tugboat and wind velocity

The conducted case study shows that sailing time for the ship in the navigational channel is up to $500 \mathrm{~s}$, stopping time - about $300 \mathrm{~s}$ and turning time - about $600 \div 700 \mathrm{~s}$; ship movement from the turning basin to the quay wall area is about $500 \mathrm{~s}$ and the total time to occupy the port area $-1200 \div 1400 \mathrm{~s}(20 \div 23 \mathrm{~min})$.

Entry and departure time for ships to Malkų Bay depends of the ship's size and is received on the basis of the methodology presented in this article and checked referring to experimental data on the ship (entry and departure time with and without a turn and the total ship's time for arrival and departure in the navigational channel and ship turning basin) displayed in Figs 9-11.

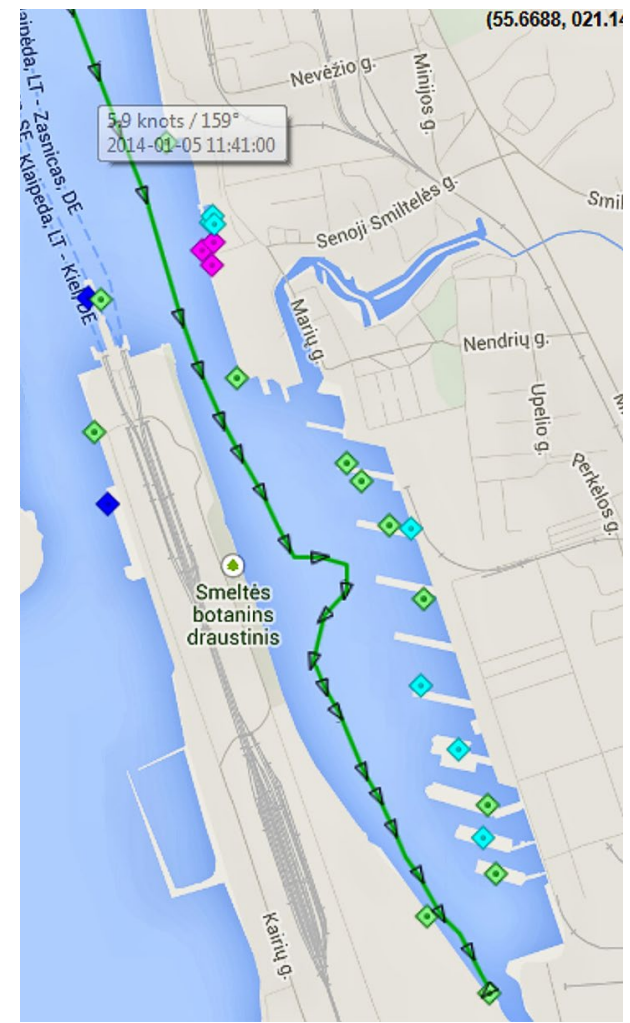

Fig. 8. A track of the real ship $(L=180 \mathrm{~m})$ sailing to Malku Bay (received by AIS devices)

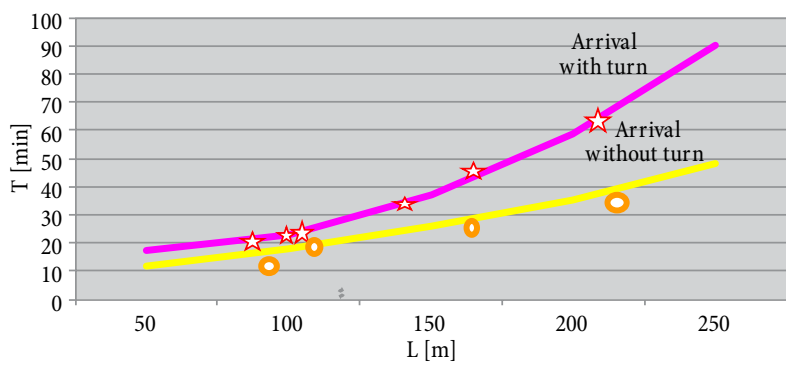

Fig. 9. Ship arrival time to Malkų Bay, including and excluding a turn, depending on the ship's length received using the calculation method and experimental data on real ships

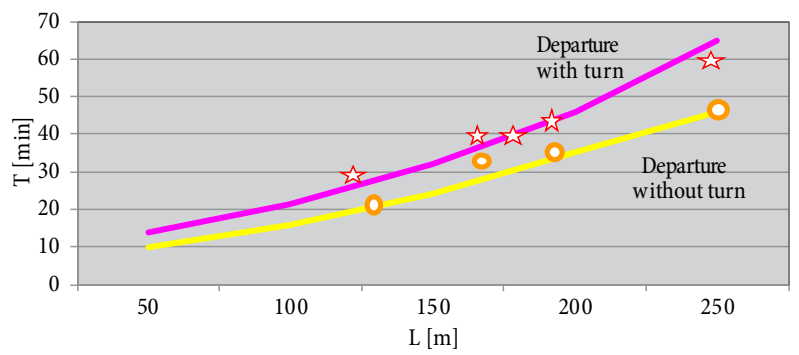

Fig. 10. Ship departure time from Malkų Bay, including and excluding a turn, depending on the ship's length received using the calculation method and experimental data on real ships

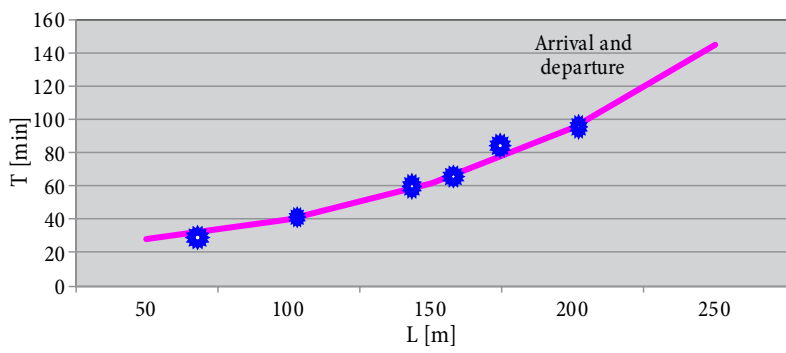

Fig. 11. The total ship arrival and departure time (ship's time in the navigational channel and turning basin) depending on the ship's length received using the calculation method and experimental data on real ships 
In all cases, the turning speed of the ship having length more than $150 \mathrm{~m}$ can be accepted up to $18 \div 20 \mathrm{deg} / \mathrm{min}$.

The maximum numbers of the ships that can enter and leave Malku Bay depend on the ship's size and the frequency of visits to Malku Bay $(k=0.4 \div 0.8)$. The main optimizing task based on calculating the exact parameters of sailing ships (stopping distances, turn areas) is solved applying the methodology presented in the article (Fig. 12).

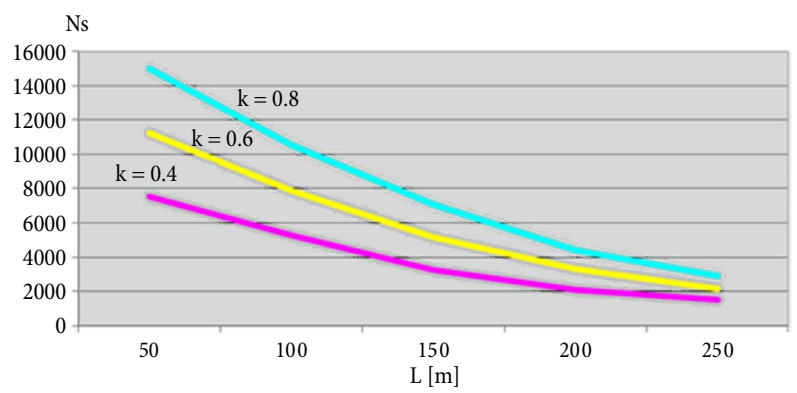

Fig. 12. The maximum number of ships depending on their size and the frequency of visits to Malku Bay received referring to theoretical methods

Theoretical calculations and a case study on optimize width of the navigational channels and ships turning basins in ports methodology have been discussed in this article and can be used in ports or port areas for enhancing and referring to the possibilities of calculating an increase in effectiveness and competiveness in ports or port areas.

\section{Conclusions}

1. Navigational channels and ships turning basins are an important part of the port and should be used to substantially increase port effectiveness and competiveness.

2. The article presents optimization methods for width of the navigational channels and ships turning basins in ports monitored employing navigational simulators under real conditions as well as show the possibility of using them in any port or port area.

3. Calculating the optimization of the width navigational channels and ships turning basins in ports could be recommended for evaluating the possibilities of ports and water ways, as well as for promoting investment in adjustments regarding the dimensions and flows of ships.

\section{References}

Baublys, A. 2003. Transport system: Models of Development and Forecast: monograph. Vilnius: Technika. $208 \mathrm{p}$.

Gucma, L.; Montewka, J. 2005. Landborne laser rangefinder measurements for navigation safety assessment, European Journal of Navigation 3(4): 1-6.

Paulauskas, V. 1999. Laivo valdymas ypatingomis salygomis. Klaipeda: Klaipèdos universiteto leidykla. 164 p. (in Lithuanian).

Paulauskas, V. 2011. Optimalus uostas: monografija. Klaipėda: Klaipedos universiteto leidykla. 320 p. (in Lithuanian).
Paulauskas, V.; Paulauskas, D. 2009. Laivo valdymas uoste. Klaipeda: Klaipedos universiteto leidykla. 256 p. (in Lithuanian).

PIANC. 2010. Recommendations on Maritime-Port and Terminal Development.

PIANC. 1997. Approach Channels a Guide to Design. Joint PIANC-IAPH Report. 108 p.

PIANC. 1995. Criteria for Movements of Moored Vessels in Harbours.

Recommendations of the Committee for Waterfront Structures Harbours and Waterways EAU 2004: Digitized and Updated Version 2009 (Digital). 2010. Wiley-VCH Verlag GmbH. $250 \mathrm{p}$.

SimFlex Navigator. 2012. Ship Simulator 2012 Full Version.

Strem, K. 2004. Ship's Handling. Force Technology, Denmark. $130 \mathrm{p}$.

Thiers, G. F.; Janssens, G. K. 1998. A port simulation model as a permanent decision instrument, Simulation 71(2): 117-125. http://dx.doi.org/10.1177/003754979807100206

Tomczak, A. 2008. Safety evaluation of ship's maneuvers carried out on the basis of integrated navigation systems (INS) indications, Journal of Konbin 4(1): 247-266. http://dx.doi.org/10.2478/v10040-008-0021-y

Zalewski, P; Montewka, J. 2007. Navigation safety assessment in an entrance channel, based on real experiments, in Proceedings of the 12th International Congress of the International Maritime Association of the Mediterranean (IMAM 2007), 2-6 September 2007, Varna, Bulgaria, 1113-1120. 